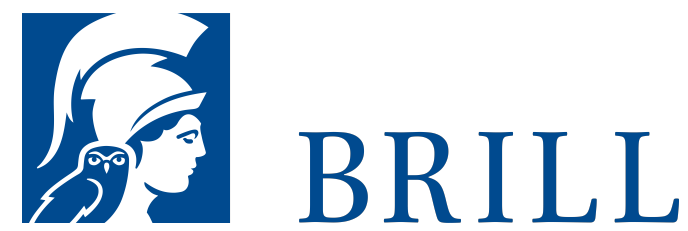

\title{
Christianity, Conflict, and Renewal in Australia and the Pacific
}

\section{Volume Editors: Fiona Magowan and Carolyn Schwarz}

Cultural expressions of Christianity show great diversity around the globe. While scholarship has tended to consider charismatic practices in distinct geographical contexts, this volume advances the anthropology of Christianity through ethnographically rich, comparative insights from across the Australia-Pacific region. Christianity, Conflict, and Renewal in Australia and the Pacific presents new perspectives on the performative dynamics of Christian belief, conflict, and renewal. Addressing experiences of cultural and spiritual renewal, contributors reveal how tensions can arise between spiritual and political expressions of culture and identity, opening up alternative spaces for spiritual realization and religious change. These local processes further mobilize responses of individuals and groups to state forces and political reforms, in turn, influencing the shape of translocal and transnational Christian practices.

Readership

This book will be key reading for professional scholars in Anthropology, Religious Studies, Ethnomusicology, Theology, Missions and Social Sciences, as well as for undergraduate and postgraduate students in related disciplines.

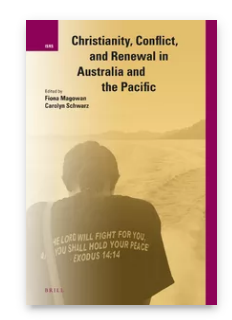

Pages: xiii, 272

pp.

Language:

English

Subjects:

Sociology \&

Anthropology,

Social Sciences,

Sociology of

Religion,

Religious

Studies,

Comparative

Religion \&

Religious

Studies,

Religious

Studies

Publisher: Brill

Series:

International

Studies in

Religion and

Society, Volume:

26

E-Book (PDF)

Released online:

21 Jun 2016

ISBN: 978-90-

O4-31145-9

List price

USD $\$ 162.00$

Hardback 
Fiona Magowan is Professor of Anthropology at Queen's University. She has published widely on Aboriginal Christianity, music, emotion and ritual. Her books include Performing Gender, Place and Emotion: Global Perspectives (2013 ed. with L. Wrazen) and Melodies of Mourning (2007).

Carolyn Schwarz is Assistant Professor of Anthropology at Goucher College. She has published articles on wellbeing, Aboriginal identity, and religion and is the co-editor of a special issue of The Australian Journal of Anthropology (2010) on Christianity in Aboriginal Australia.

Contributors are: Diane Austin-Broos, John Barker, Alison Dundon, Yannick Fer, Kirsty Gillespie, Jessica Hardin, Rodolfo Maggio, Fiona Magowan, Gwendoline Malogne-Fer, Debra McDougall, Joel Robbins, Carolyn Schwarz, and John Taylor.

For more information see brill.com

Order information: Order online at brill.com +44330 3330049 | customerservices@brill.com Submission information: brill.com/authors

Titles published by Brill | Fink, Brill | mentis or Brill | Schöningh: +49(o)71 5413279216 | brill@brocom.de 